\title{
The Efforts to Improve Thematic Learning Critical Thinking Skill through Problem Based Learning
}

\author{
Pindi Darma Hutama ${ }^{1}$, Naniek Sulistya Wardani ${ }^{2}$, Intan Permana 3
}

DOI: 10.35445/alishlah.v13i1. 462

\begin{tabular}{l}
\hline Info Artikel \\
\hline Keywords: \\
Critical thinking \\
Problem Based Learning \\
Thematic Integrative \\
Learning
\end{tabular}

\section{Abstract}

This study aims to find out whether the improvement of critical thinking skills in thematic learning can be attempted through Problem Based Learning. Moreover, it also wants to know how is the improvement of critical thinking skills student in thematic learning can be attempted through Problem Based Learning. The subjects of this research were class III students, even semester totaling 20 students. The type of this study was classroom action research (CAR). The model of CAR was spiral-shaped from Kemmis and Robin Mc. Tagget. The procedure of this study was implemented at least two cycles if cycle one was already improved. The observation was used in the data collecting. The study instrument used an observation sheet equipped with a performance appraisal rubric. The analysis data technique used was descriptive comparative technique. The result of the study stated that there was an improvement on critical thinking skills students in the thematic learning that PBL attempted had proven. The improvement of the number of skilled in good critical thinking was $15 \%$ in cycle 1 , and $40 \%$ from the totaling students in cycle 2 . The improvement of critical thinking skills in the students grade III in the thematic learning was attempted through PBL with steps of 1) reviewing problems by taking notes, 2) asking 3 energy source problems, 3) reasoning solving 3 problems of energy sources, 4) collecting data of energy sources, 5 ) analyzing data of energy sources, 6) writing report of the result of solving 3 problems of energy sources, 7) presenting the result of solving the problem of energy sources, 8) evaluating the process of energy sources problem-solving.

Kata kunci:

Berpikir kritis

Problem Based Learning

Pembelajaran Tematik integratif

\begin{abstract}
Abstrak
Penelitian ini bertujuan untuk mengetahui apakah peningkatan keterampilan berpikir kritis peserta didik dalam pembelajaran tematik dapat diupayakan melalui Problem Based Learning (PBL) dan bagaimanakah peningkatan keterampilan berpikir kritis peserta didik dalam pembelajaran tematik dapat diupayakan melalui PBL. Subjek penelitian ini adalah peserta didik kelas III SD semester genap yang berjumlah 20 peserta didik. Jenis penelitian ini adalah penelitian tindakan kelas (PTK). Model PTK berbentuk spiral dari Stephen Kemmis dan Robin Mc. Taggart. Prosedur penelitian dilaksanakan dua siklus, dan setiap siklus mengalami peningkatan. Teknik pengumpulan data menggunakan observasi. Instrumen penelitian berupa lembar observasi yang dilengkapi dengan rubrik penilaian kinerja. Teknik analisis data adalah teknik deskriptif komparatif. Hasil dari penelitian
\end{abstract}

\footnotetext{
${ }^{1}$ Universitas Kristen Satya Wacana, Salatiga, Indonesia Email: pindidarmahutama15@gmail.com 2 Universitas Kristen Satya Wacana, Salatiga, Indonesia Email: naniek.wardani@uksw.edu

3 Universitas Kristen Satya Wacana, Salatiga, Indonesia Email: trifosaintanpermana@gmail.com
} 
menyatakan bahwa terdapat peningkatan keterampilan berpikir kritis siswa kelas III dalam pembelajaran tematik yang diupayakan melalui PBL terbukti. Peningkatan jumlah peserta didik yang terampil berpikir kritis dengan baik sebanyak $15 \%$ pada siklus 1 dan $40 \%$ dari seluruh peserta didik pada siklus 2. Peningkatan keterampilan berpikir kritis siswa kelas III dalam pembelajaran tematik diupayakan melalui PBL dengan langkah-langkah: 1) mereview masalah dengan mencatat 3 masalah sumber energi, 2) menanya 3 masalah sumber energi, 3) Menalar pemecahan 3 masalah sumber energi, 4) Mengumpulkan data sumber energi 5) Menganalisis data sumber energi. 6) menulis laporan hasil penyelesaian 3 masalah sumber energi, 7) menyajikan hasil penyelesaian masalah sumber energi, 8) mengevaluasi proses pemecahan masalah sumber energi.

\section{PENDAHULUAN}

Perkembangan bidang teknologi serta ilmu pengetahuan pada abad 21 menuntut setiap elemen kehidupan khususnya dalam pendidikan agar terus berbenah dan mengikuti perkembangan yang terjadi. Kemajuan pembelajaran masa kini adalah dengan adanya desain pembelajaran tematik yang dimana mengintegrasikan berbagai mata pelajaran sehingga menjadi satu pembelajaran utuh yang dimasukkan kedalam tema dan subtema pembelajaran. Pembelajaran tematik difokuskan terhadap pelaksanan pembelajaran dengan memberikan pengalaman pada peserta didik dalam mencari serta memahami konsep keilmuan holistik, memiliki arti, serta asli (Rusman, 2012). Sesuai dengan Peraturan Menteri Pendidikan dan Kebudayaan Nomor 67 tahun 2013 ialah pembelajaran dengan tematik integratif merupakan sistem pembelajaran yang menggabungkan lebih dari satu kompetensi yang mencakup lebih dari satu mata pelajaran lalu menjadi tema sebuah pembelajaran. Karakteristik dari pembelajaran yang menerapkan tematik integratif adalah pembelajaran dengan sistem berpusat pada peserta didik dan muatan materi dipembelajaran yang disampaikan mampu membuat peserta didik memiliki pengalaman (Mustamilah, 2015). Pembelajaran yang berlangsung harus memberikan pengalaman yang dapat memberikan perubahan dalam individu. Menurut (Yuyu Yuliati ; Dudu Suhandi Saputra, 2019). Salah satu keberhasilan dari pelaksanana pembelajaran adalah adanya perubahan tingkah laku atau pola pikir dari peserta didik sebagai bentuk meningkatnya kemampuan dan keterampilan diri. Pendidikan adalah cara memberikan latihan, sehingga dalam pelaksanaanya harus memberikan pengalaman dan kesiapan peserta didik dalam melakukan tindakan penyelesaian terhadap permasalahan yang ditemukan dikehidupannya secara kemampuan yang mengandalkan respon yang baik terhadap perubahan dan masalah dengan cara berpikir kritis. Sedangkan menurut (Widana, 2018) keterampilan berpikir kritis peserta didik adalah keterampilan yang harus dikembangkan dalam pembelajaran dengan cara dilatih, dibiaskan, dan dipraktikkan dalam pembelajaran dan direlavankan dengan kehidupan sehari-hari.

Keterampilan peserta didik untuk mampu berpikir kritis adalah sebuah keterampilan peserta didik yang terampil dalam memberikan penjelasan, memberikan penilaian dasar terhadap keputusan, menduga, dan membuat suatu pengandaian terhadap suatu permasalahan (Kuswana, 2013). Menurut (Alghafri \& Ismail, 2014) Keterampilan dalam berpikir kritis merupakan sebuah keterampilan yang menuntut seseorang yang logis dalam menyelesaikan sebuah pertanyaanpertanyaan atau menyampaikan jawaban dari penyelesaian permasalahan yang terjadi dengan menyertakan alasan atau bukti yang jelas. Sedangkan menurut (Eriyanti \& Suryanti, 2018) dalam langkah berpikir kritis peserta didik dintuntut untuk mampu menyertakan identifikasi masalah, merumuskan masalah, menganalisis data, mensintesis data, memecahkan masalah, menarik kesimpulan, dan mengevaluasi. Maka, keterampilan berpikir kritis dapat disimpulkan bahwa keterampilan yang melatih peserta didik untuk menyelesaikan masalah dengan cara mengidentifikasi, merumuskan, menganalisis data, dan menyampaikan hasil penyelesaian masalah dengan baik. Dilihat dari sistem pembelajaran yang berlangsung, keterampilan peserta didik dalam berpikir kritis yang dimiliki tidak didapatkan dengan instan. Keterampilan berpikir kritis pada peserta didik didapat dengan cara memberikan pelatihan dan mendesain pembelajaran yang 
menyenangkan serta memberikan pembelajaran yang menanamkan pengalaman berpikir kritis setelah pembelajaran selesai.

Proses keterampilan pada peserta didik dalam berpikir kritis yang dilaksanakan ketika pembelajaran dapat didesain menggunakan Problem Based Larning (PBL). Desain pembelajaran pelaksanan yang inovatif dan mampu untuk memberikan latihan pada peserta didik yang memiliki manfaat meningkatkan keterampilan berpikir kritis adalah pembelajaran yang didesain dengan pendekatan PBL. PBL menuntut peserta didik dihadapkan dengan permasalahan yang relevan terhadap kehidupan peserta didik yang diselesaiakn secara individu atau kelompok (Mawardi, 2018). PBL adalah suatu pendekatan pembelajaran dengan menghadapkan peserta didik untuk mempau menyelesaikan masalah nyata.

Berdasar observasi dan wawancara di Kelas III SD semester genap, ditemukan 14 dari 20 peserta didik dinilai belum mampu untuk mengidentifikasi masalah-masalah yang diberikan oleh pengajar sehingga saat proses pembelajaran pendidik masih memiliki peran dominan ketika proses pembelajaran. Hal ini tentu tidak seperti tujuan pendidikan di era abad 21 yang diharapkan peran guru sebagai fasilitator sedangkan proses pembelajaran merujuk pada peserta didik sebagai poros atau student center. Dalam pelaksanan pembelajaran peserta didik di kelas juga belum terbiasa untuk menulis dan membuat hasil pengamatan dengan runtut. Proses pelaksanan pembelajaran selama ini terbiasa dengan selalu menyampaikan hasil pengamatan dengan lisan dan tidak melakukannya secara tertulis sebagai bentuk laporan hasil pengamatan. Kurangnya latihan dalam menulis laporan membuat 12 dari 20 peserta didik tidak terbiasa dalam penulisan laporan pelaksanan kegiatan pembelajaran. Dalam proses diskusi atau penyampaian pendapat, peserta didik cenderung pasif dengan tidak menanggapi permasalahan-permasalahan yang disampaikan ketika pembelajaran. Kejadian yang muncul berakibat peserta didik tidak mampu berlatih untuk berpendapat dan merespon terhadap hasil laporan peserta didik lainnya. Dengan pasifnya peserta didik cenderung membuat pembelajaran menjadi monoton. Tidak terdapatnya langkah pembelajaran yang saling berpendapat dan menyelesaikan masalah membuat peserta didik tidak mampu untuk mengembangkan keterampilan berpikir kritis dalam dirinya untuk memahami materi ajar yang disampaikan selama proses pelaksanaan pembelajaran.

Permasalahan pembelajaran yang muncul pada kelas adalah permasalahan diketerampilan berpikir kritis peserta didik yang belum terlatih. Permasalahan pada keterampilan berpikir kritis peserta didik bisa dibiasakan dan diajarkan dengan langkah mendesain pengajaran yang inovatif dengan memberikan latihan untuk melatih keterampilan peserta didik agar mampu berpikir kritis pada peserta didik. Permasalahan yang terjadi dipembelajaran ialah masalah yang urgent dan mendesak untuk dapat diselesaikan. Untuk itu, tujuan dari pelaksanaan penelitian ialah agar mampu mengetahui: 1). Apakah pembelajaran yang menerapkan pendekatan PBL dapat meningkatkan keterampilan berpikir kritis bagi peserta didik kelas III SD semester 2, 2). Bagaimana pembelajaran dengan PBL yang dapat meningkatkan keterampilan berpikir kritis untuk peserta didik di kelas III SD semester 2.

Permasalahan yang disampaikan selama pembelajaran dan ditujukan bagi peserta didik ialah permasalahan nyata dan terjadi pada lingkungan kehidupan peserta didik. Tugas pesertadidik adalah melakukan pemecahkan masalah dari guru dengan tujuan guna peningkatan pengetahuannya sendiri serta dapat meningkatkan keterampilan berpikir kritis pada peserta didik. PBL mengajarkan peserta didik untuk mampu bekerjasama dengan tujuan untuk memecahkan masalah dan mampu menghasilkan peningkatan pengalaman dalam proses pembelajaran (Nurul 'azizah \& Wardani, 2019).

Meningkatkan keterampilan untuk mampu berpikir kritis pada peserta didik mampu diupayakan menggunakan pembelajaran inovatif yang membuat peserta didik berorientasi pada masalah guna memberikan latihan bagi peserta didik agar memiliki keterampilan berpikir krtis (Puisi et al., 2013). Desain pembelajaran yang inovatif mampu membantu latihan untuk peserta 
didik sebagai upaya peningkatan keterampilan berpikir kritis adalah pembelajaran dengan pendekatan Problem Based Learning. Menurut (Huda, 2013) Pendekatan Problem Based Learning adalah rangkaian kegiatan belajar mengajar yang mengarahkan peserta didik belajar penyelesaian masalah dan mendapatkan pengetahuan yang baru. Sedangkan menurut (Suyatno, 2009) Problem Based Learning ialah desain yang dimulai dengan permasalahan relevan dalam kehidupan. Peserta didik dirangsang agar mampu menganalisis masalah berdasar pada pengetahuan serta pengalaman mereka miliki yang bertujuan untuk mendapatkan pengetahuan dan pengalaman yang baru bagi peserta didik. Menurut (Rahmadani \& Anugraheni, 2017) Pendekatan PBL mengajarkan masalah pada kehidupan sebenarnya sebagai rangsangan bagi peserta didik melatih serta mengembangkan tingkat keterampilan berpikir kritis. Dari berbagai ahli yang mengemukakan pendapat. Simpulannya bahwa, Problem Based Learning merupakan desain pembelajaran yang berkaitan langsung dikehidupan nyata dari peserta didik yang dapat memberikan pengalaman dan pelatihan untuk peserta didik memahami masalahnya dikehidupan sehari-hari dan menyelesaikan bebagai masalah yang ada dengan baik. Pelaksanaan pembelajaran yang menerapkan pendekatan Problem Based Learning mampu membentuk pengalaman baru untuk peserta didik dan pembelajaran yang menerapaan Problem Based Learning merupakan alternatif dari pemecahan masalah yang muncul di kelas karena pembelajaran dengan Problem Based Learning mendorong peserta didik supaya mampu menjawab masalah yang diberikan secara sistematis. Dengan demikian, teachers are facilitators who help students if they ask for it (Wardani, 2014)

Pembelajaran dengan Problem Based Learning mendesain peserta didik dengan masalah yang relevan terhadap dunia nyata serta menyusun pemecahan masalah dengan cara individu atau berkelompok (Mawardi, 2018) Problem Based Learning ialah pendekatan kegiatan belajar dengan bentuk pembelajaran yang menghadapkan peserta didik dengan masalah nyata untuk diselesaikan. Masalah yang disampaikan untuk peserta didik adalah masalah-masalah nyata yang ada di lingkungan kehidupan peserta didik. Pembelajaran membentuk peserta didik agar mampu mencari solusi dari masalah yang memiliki tujuan untuk mengembangkan pengetahuannya sendiri serta dapat meningkatkan keterampilan peserta didik supaya mampu berpikir kritis.

Karakteristik PBL yang menonjolkan permasalahan dalam pembelajaran dan menyelesaikan masalah sebagai proses pembelajarannya memiliki langkah kegiatan yaitu: mengorientasi peserta didik terhadap masalah, menjelaskan tujuan dari pembelajaran, menguraikan hal yang perlu disiapkan untuk menyelesaikan masalah, memberi semangat untuk peserta didik agar aktif selama proses pembelajaran, menkoordinir peserta didik untuk belajar, mengumpulkan informasi, menulis laporan hasil pengumpulan data penyelesaian masalah, mengkomunikasikan hasil penyelesaian masalah (Rahmadani \& Anugraheni, 2017). Menurut (Eggen \& Kauchak, 2012) pembelajaran PBL terdiri atas beberapa susunan ketika diterapkan dipembelajaran yaitu: (1) Melakukan kajian serta penyampaikan masalah, (2) Menyusun rencana, (3) Melaksanakan, (4) Melakukan pembahasan dan mengevaluasi hasil. Langkah-langkah PBL ini dengan baik. PBL menurut (Hosnan, 2014) mengemukakan bahwa pelaksanaan kegaiatan pembelajaran PBL yaitu: (1) Pengenalan masalah. (2) Melakukan koordinasi peserta didik untuk belajar. (3) Membimbing pemecahan masalah. (4) Merangkum serta menyajikan hasil. (5) Melakukan analisis serta mengevaluasi proses pemecahan masalah. Sedangkan menurut (Mulyasa, 2014) langkah pelaksanaan PBL yaitu: (1) Melakukan pengenalan peserta didik dengan masalah, (2) Melakukan kontrol sistem belajar peserta didik , (3) Membimbing pelaksanaan penyelidikan, (4) Melakukan pengembangan dan penyajian hasil, (5) Menganalisis dan mengevaluasi terhadap proses pemecahan masalah. Maka, dari berbagai pendapat simpul dari pendapat ahli bahwa langkah pembelajaran PBL: (1) Mereview masalah, (2) Menanya masalah nyata, (3) Menalar proses pemecahan masalah, (4) Mengumpulkan data. (5) Menganalisis data. (6) menulis laporan hasil penyelesaian masalah, (7) menyajikan hasil penyelesaian masalah, dan (8) mengevaluasi proses pemecahan masalah

Pembelajaran PBL dapat membentuk pembelajaran menarik serta membentuk peserta didik memiliki peran aktif selama proses pembelajaran. Karena seperti pada tujuan pembelajaran pada 
abad 21 dengan tuntutan peserta didik berperan aktif dalam pembelajaran. Ketika saat proses pembelajaran juga guru bertindak untuk menjadi fasilitator serta pembimbing yang perannya adalah mengarahkan langkah pembelajaran. Penerapan pembelajaran dengan PBL diupayakan untuk meningkatkan peserta didik dalam keterampilan berpikir kritis.

Pengukuran keterampilan dalam berpikir kritis dapat melalui penilaian otentik baik penilaian sikap, penilaian pengetahuan, dan penilaian keterampilan. Penggunaan teknik penilaian untuk mengukur kompetensi keterampilan kinerja yaitu, penilaian yang dituntut bagi peserta didik yang mampu melakukan peragaan kompetensi dengan menggunakan tes praktek, hasil kerja, serta penilaian pada portofolio (Wardani NS, 2016). Penilaian kinerja dilakukan dengan melakukan observasi, unjuk kerja, dan studi dokumentasi.

Permasalahan pembelajaran peserta didik kelas III SD adalah kurang terampilnya dalam berpikir kritis untuk menyelesaikan masalah dengan cara mengidentifikasi, merumuskan, menganalisis data, dan menyampaikan hasil penyelesaian masalah dengan baik. Keterampilan peserta didik dalam berpikir kritis tidak didapatkan dengan cara instan. Salah satu bentuk usaha guna meningkatkan keterampilan berpikir kritis adalah dengan mendesain pembelajaran yang mengimplementasikan pendekatan PBL. Desain pembelajaran PBL yang memotivasi peserta didik untuk berpikir kritis dengan melakukan langkah-langkah: (1) Mereview masalah dengan mencatat 3 masalah sumber energi, (2) Menanya 3 masalah sumber energi, (3) Menalar pemecahan 3 masalah sumber energi, (4) Mengumpulkan data sumber energi (5) Menganalisis data sumber energi. (6) Menulis laporan hasil penyelesaian 3 masalah sumber energi, (7) Menyajikan hasil penyelesaian masalah sumber energi dan (8) Mengevaluasi proses pemecahan masalah sumber energi. Pembelajaran tematik peserta didik kelas III SD didesain menggunakan Tema 6 Energi Subtema 1 Sumber energi dan Subtema 2 Energi dan Perubahannya.

Pelaksanaan pembelajaran yang menerapkan Problem Based Learning tidak lagi asing didunia pendidikan. Ragam penelitian yang menerapkan Problem Based Learning untuk meningkatkan keterampilan peserta didik dalam berpikir kritis telah dilakukan oleh (Nismaya, 2020) dengan hasil terdapat peningkatan pada keterampilan peserta didik untuk berpikir kritis pada siklus satu dengan rata-rata skor berpikir kritis sebesar 1,95 dengan kriteria tidak baik, pada siklus dua menjadi 2,57 dengan kriteria kurang baik, dan pada siklus tiga menjadi 3.04 dengan kriteria baik. Penelitian juga telah dilakukan oleh (Fakhrizal \& Hasanah, 2020) dengan hasil yang diperoleh bahwa terdapat peningkatan keterampilan berpikir kritis peserta didik ketika siklus 1 sebanyak 51,80\% masuk dalam kategori cukup kritis dan meningkat pada siklus 2 menjadi 76,90\% dengan kategori kritis. Berbagai penelitian yang menggunakan pembelajaran yang menerapkan Problem Based Learning bentuk upaya peningkatan keterampilan peserta didik untuk berpikir kritis dan membuktikan bahwa pembelajaran dengan menerapkan Problem Based Learning mampu untuk meningkatkan keterampilan peserta didik agar mampu untuk berpikir kritis.

Pelaksanaan penelitian dilakukan atas dasar hasil observasi terhadap peserta didik di kelas III SD N 10 Purwodadi tahun ajaran 2020/2021 dimana kurangnya keterampilan berpikir kritis pada peserta didik. Penelitian dengan penerapan desain pembelajaran Problem Based Learning memang sudah banyak dilakukan, namun untuk penelitian yang khusus dalam melakukan peningkatan keterampilan peserta didik untuk mampu berpikir kritis masih belum banyak dilakukan karena kebanyakan dari penelitian yang telah dilakukan tidak terfokus dengan keterampilan berpikir kritis saja dari peserta didik. Sehingga, perbedaan yang yang ada pada pelaksanan penelitian ini adalah terdapat 7 indikator keterampilan peserta didik untuk berpikir kritis dari peserta didik sehingga peningkatan keterampilan peserta didik melalui pembelajaran PBL dapat diasah dengan baik. Penelitian ini juga memiliki tujuan untuk membantu guru sebagai bahan pertimbangan bahwa peningkatan keterampilan berpikir kritis dari peserta didik mampu ditingkatkan dengan pendekatan Problem Based Larning pada proses pembelajaran. 


\section{METODE}

Pelaksanana penelitian ini dilakukan di SDN 10 Purwodadi Kabupaten Grobogan semester II tahun 2020/2021. Subjek dari pelaksanan penelitian ini adalah peserta didik di kelas III yang terdapat 20 peserta didik. Jenis penelitian ini menggunakan penelitian tindakan kelas (PTK) dan menggunakanmodel PTK spiral oleh Stephen Kemmis dan Robin Mc. Taggart. Pelaksanaan penelitian memiliki prosedur dua siklus. Setiap pelaksanaan siklus melaksanakan 3 tahap dengan tahap perencanaan, tahap pelaksanaan serta observasi, dan tahap refleksi. Dalam pengumpulan data menggunakan teknik observasi. Instrumen berupa lembar observasi yang juga dilengkapi rubrik penilaian kinerja. Teknik analisis yang digunakan untuk pengolahan data adalah teknik deskriptif komparatif. Prosedur penelitian secara dijelaskan di gambar 1 berikut ini.

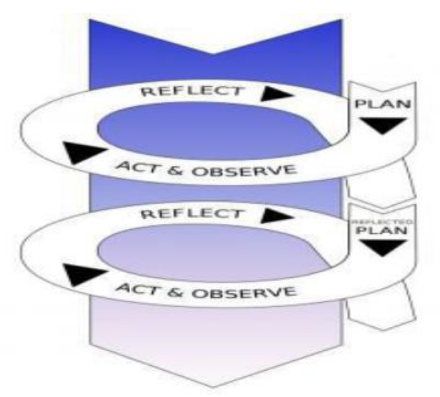

\section{Gambar 1. PTK Model Spiral Stephen Kemmis dan Robin Mc. Taggart}

Langkah-langkah pembelajaran PBL yang diterapka sebagai peningkatkan keterampilan berpikir kritis dengan Tema enam "Energi dan Perubahannya" Subtema dua dan tiga melalui langkah pembelajaran: (1) Mereview masalah dengan mencatat 3 masalah sumber energi, (2) Menanya 3 masalah sumber energi, (3) Menalar pemecahan 3 masalah sumber energi, (4) Mengumpulkan data sumber energi. (5) Menganalisis data sumber energi. (6) menulis laporan hasil penyelesaian 3 masalah sumber energi. (7) Menyajikan hasil penyelesaian masalah sumber energi. (8) Mengevaluasi proses pemecahan masalah sumber energi. Secara rinci, penjelasan peningkatan berpikir kritis melalui PBL dalam gambar 2 berikut ini:

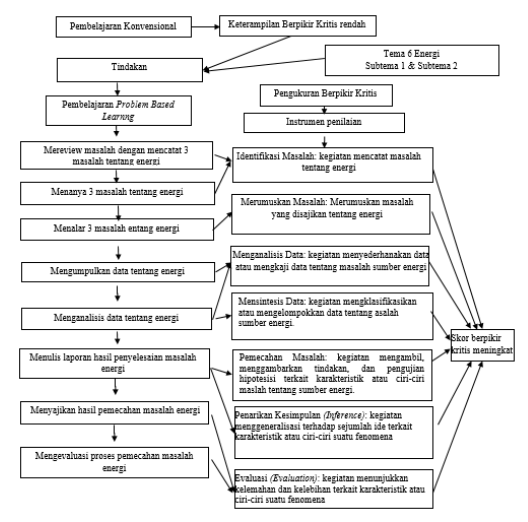

\section{Gambar 2. Kerangka Berpikir Peningkatan Berpikir Kritis Melalui PBL}

Jenis data dalam pengolahan yang dipakai ialah data primer atau data yang diperoleh ketika penelitian dilaksanakan dari lapangan hasil observasi sdan unjuk kerja serta data sekunder berupa data dokumentasi, studi dokumentasi digunakan untuk memperoleh data seperti daftar foto pelaksanaan pembelajaran. Teknik untuk mengumpulkan data ialah observasi, unjuk kerja, dan studi dokumentasi. Metode observasi digunakan untuk mengamati jalannya pembelajaran PBL dan unjuk kerja guna mengukur keterampilan peserta didik dalam berpikir kritis dengan berbantu 
instrumen penilaian keterampilan. Instrumen keterampilan berpikir kritis secara rinci disajikan dalam table 1 berikut.

Tabel 1. Instrumen Keterampilan Peserta Didik untuk Berpikir Kritis

\begin{tabular}{|c|c|c|c|}
\hline No & $\begin{array}{c}\text { Kriteria Keterampilan } \\
\text { BerpikirKritis }\end{array}$ & Skala & Skor \\
\hline \multirow[t]{3}{*}{1.} & \multirow{3}{*}{$\begin{array}{l}\text { Identifikasi Masalah } \\
\text { (Identification): kegiatan } \\
\text { mencatat } 3 \text { masalah energi }\end{array}$} & Peserta didik mampu mencatat 3 permasalahan energi. & 3 \\
\hline & & $\begin{array}{l}\text { Peserta didik mampu mencatat } 2 \text { dari } 3 \text { permasalahan } \\
\text { energi. }\end{array}$ & 2 \\
\hline & & $\begin{array}{l}\text { Peserta didik mampu mencatat } 1 \text { dari } 3 \text { permasalahan } \\
\text { energi. }\end{array}$ & 1 \\
\hline \multirow[t]{3}{*}{2.} & \multirow{3}{*}{$\begin{array}{l}\text { Merumuskan Masalah } \\
\text { (Formulate): merumuskan } \\
\text { masalah tentang energi }\end{array}$} & Peserta didik mampu merumuskan 3 masalah energi & 3 \\
\hline & & $\begin{array}{l}\text { Peserta didik mampu merumuskan } 2 \text { dari } 3 \text { masalah } \\
\text { energy }\end{array}$ & 2 \\
\hline & & $\begin{array}{l}\text { Peserta didik mampu merumuskan } 1 \text { dari } 3 \text { masalah } \\
\text { energi. }\end{array}$ & 1 \\
\hline \multirow[t]{3}{*}{3.} & \multirow{3}{*}{$\begin{array}{l}\text { Menganalisis Data (Analysis): } \\
\text { kegiatan menyederhanakan } \\
\text { data atau mengkaji data }\end{array}$} & $\begin{array}{l}\text { Peserta didik mampu menganalisis } 3 \text { permasalahan } \\
\text { tentang energi. }\end{array}$ & 3 \\
\hline & & $\begin{array}{lllll}\text { Peserta didik mampu menganalisis } & 2 & \text { dari } & 3 \\
\text { permasalahan tentang energi. }\end{array}$ & 2 \\
\hline & & 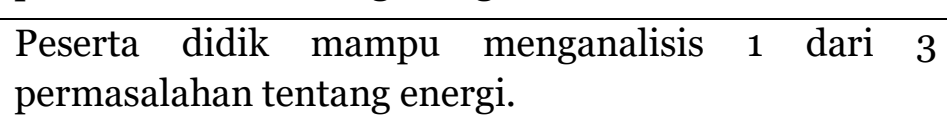 & 1 \\
\hline \multirow[t]{3}{*}{4.} & \multirow{3}{*}{$\begin{array}{l}\text { Mensintesis Data (Syhtesis): } \\
\text { kegiatan mengklasifikasikan } \\
\text { atau mengelompokkan data }\end{array}$} & $\begin{array}{lll}\text { Peserta didik mampu mengklasifikasikan } & 3 \\
\text { permasalahan tentang energi. } & & \end{array}$ & 3 \\
\hline & & $\begin{array}{l}\text { Peserta didik mampu mengklasifikasikan } 2 \text { dari } 3 \\
\text { permasalahan tentang energi. }\end{array}$ & 2 \\
\hline & & $\begin{array}{l}\text { Peserta didik mampu mengklasifikasikan } 1 \text { dari } 3 \\
\text { permasalahan tentang energi. }\end{array}$ & 1 \\
\hline \multirow[t]{3}{*}{5.} & \multirow{3}{*}{$\begin{array}{l}\text { Pemecahan Masalah: kegiatan } \\
\text { mengambil, menggambarkan } \\
\text { tindakan, dan pengujian } \\
\text { hipotesisi terkait karakteristik } \\
\text { atau ciri-ciri suatu fenomena }\end{array}$} & $\begin{array}{l}\text { Peserta didik mampu menemukan } 3 \text { solusi terkait } \\
\text { permasalahan energi. }\end{array}$ & 3 \\
\hline & & $\begin{array}{l}\text { Peserta didik mampu menemukan } 2 \text { dari } 3 \text { solusi } \\
\text { permasalahan tentang energi. }\end{array}$ & 2 \\
\hline & & $\begin{array}{l}\text { Peserta didik mampu menemukan } 1 \text { dari } 3 \text { solusi } \\
\text { permasalahan tentang energi. }\end{array}$ & 1 \\
\hline \multirow[t]{3}{*}{6.} & \multirow{3}{*}{$\begin{array}{l}\text { Penarikan Kesimpulan } \\
\text { (Inference): kegiatan } \\
\text { menggeneralisasi terhadap } \\
\text { sejumlah ide terkait } \\
\text { karakteristik atau ciri-ciri } \\
\text { suatu fenomena }\end{array}$} & $\begin{array}{l}\text { Peserta didik mampu menarik } 3 \text { kesimpulan tentang } \\
\text { pemecahan permasalahan energi. }\end{array}$ & 3 \\
\hline & & $\begin{array}{l}\text { Peserta didik mampu menarik kesimpulan } 2 \text { dari } 3 \\
\text { pemecahan permasalahan energi. }\end{array}$ & 2 \\
\hline & & $\begin{array}{l}\text { Peserta didik mampu menarik kesimpulan } 1 \text { dari } 3 \\
\text { pemecahan permasalahan energi. }\end{array}$ & 1 \\
\hline \multirow[t]{3}{*}{7.} & \multirow{3}{*}{$\begin{array}{l}\text { Evaluasi (Evaluation): } \\
\text { kegiatan menunjukkan } \\
\text { kelemahan dan kelebihan } \\
\text { terkait karakteristik atau ciri- } \\
\text { ciri suatu fenomena }\end{array}$} & $\begin{array}{l}\text { Peserta didik mampu menunjukkan kelemahan dan } \\
\text { kelebihan tentang energi masing-masing } 3\end{array}$ & 3 \\
\hline & & $\begin{array}{l}\text { Peserta didik mampu menunjukkan kelemahan dan } \\
\text { kelebihan tentang energi masing-masing } 2\end{array}$ & 2 \\
\hline & & $\begin{array}{l}\text { Peserta didik mampu menunjukkan kelemahan dan } \\
\text { kelebihan tentang energi masing-masing } 1\end{array}$ & 1 \\
\hline
\end{tabular}




\section{HASIL PENELITIAN DAN PEMBAHASAN}

Peningkatan keterampilan peserta didik dalam berpikir kritis di kelas III diupayakan dengan pemberian tindakan berupa PBL. Pelaksanaan tindakan menggunakan model PTK spiral dari Stephen Kemmis dan Robin Mc. Taggart. Penelitian menggunakan prosedur dua siklus yakni siklus satu dan siklus dua. Setiap pelaksanaan siklus terdiri atas 3 tahap yaitu: tahap perencanaan, tahap pelaksanaan serta observasi, dan tahap refleksi.

Tahap 1 adalah tahap perencanaan tindakan. Pada tahap 1 menyusun perangkat pembelajaran tema "Energi dan Perubahannya" subtema "Sumber Energi" dan "Perubahan Energi". Muatan pembelajaran adalah Bahasa Indonesia, Matematika, dan SBdP. Dalam tahap 1, hal yang perlu disiapkan adalah membuat perangkat pembelajaran meliputi: Rencana Pelaksanaan Pembelajaran (RPP), materi, media, lembar kegiatan peserta didik (LKPD) dan evaluasi. RPP disusun berdasarkan permasalahan yang muncul.

Tahap ke-2 implementasi perangkat pembelajaran yang sudah dirancang. Ketika proses kegiatan pembelajaran juga dilakukan observasi oleh teman. Observasi dilakukan untuk mengetahui keterlaksanaan pembelajaran apakah sudah sesuai dengan perangkat pembelajaran yang telah disusun. Untuk membantu keterlaksanaan observasi dilakukan oleh teman sejawat dan lembar observasi. Selain itu, observasi dilakukan untuk memudahkan evaluasi dalam pelaksanaan pembelajaran. Proses pembelajaran meliputi: kegiatan pendahuluan, kegiatan inti, dan kegiatan penutup. Dalam kegiatan pembelajaran peserta didik diberikan link pertemuan melalui pesan grup whatsapp, pada pelaksanaan pembelajaran tahap pendahuluan peseta didik bersama guru melakukan doa pembuka pembelajaran kemudian dilanjutkan dengan kegiatan guru melakukan presensi kehadiran peserta didik. Guru melanjutkan dengan melakukan apresepsi pembelajaran serta disampaikan tujuan dari kegiatan pembelajaran. Ketika tahap kegiatan inti guru memaparkan materi pembelajaran, dalam pelaksanaan pembelajaran guru memfasilitasi peserta didik untuk mampu melaksanakan pembelajaran dengan keterampilan berpikir kritis melalui tahap: (1) Mereview masalah dengan mencatat 3 masalah sumber energi, (2) Menanya 3 masalah sumber energi, (3) Menalar pemecahan 3 masalah sumber energi, (4) Mengumpulkan data sumber energi, (5) Menganalisis data sumber energi, (6) Menulis laporan hasil penyelesaian 3 masalah sumber energi, (7) Menyajikan hasil penyelesaian masalah sumber energi, (8) mengevaluasi proses pemecahan masalah sumber energi. Dalam pembelajaran, peserta didik berlatih untuk mampu mengidentifikasi masalah, merumuskan masalah, menganalisis data, mensintesis data, memecahkan masalah, menarik kesimpulan dan mengevaluasi hasil pemecahan masalah. Untuk menutup pembelajaran guru tidak lupa untuk melakukan refleksi pembelajaran serta melaksanakan do'a yang dipimpin oleh perwakilan peserta didik.

Tahap ke-3 merupakan tahap refleksi. Kegiatan refleksi dilakukan setelah seluruh pelaksanaan pembelajaran. Kelemahan yang terjadi pada pembelajaran siklus 1 adalah kurangnya persiapan guru dalam pembelajaran sehingga guru kurang dapat memperhatikan aturan-aturan atau kontrak pembelajaran diawal pada peserta didik. Dalam pelaksanaan pembelajaran, guru juga belum sepenuhnya menjadi fasilitator. Peserta didikjuga masih kurang aktif dalam pembelajaran, sehingga konsep student center belum dapat terlaksana dengan baik. Dengan demikian peserta didik kurang terbiasa dengan pembelajaran aktif. Berdasar pada hasil evaluasi pembelajaran siklus 1, pada pelaksanan pembelajaran siklus 2 guru sudah mampu menjadi fasilitator saat proses belajar mengajar. Guru jauh lebih siap dalam pelaksanan pembelajaran sehingga mampu untuk dapat mengakomodasi perkembangan keterampilan peserta didik untuk dapat berpikir kritis. Aturan pembelajaran yang dapat menjaga kondisi kelas tetap kondusif sudah diberikan dalam pelaksanan pembelajaran siklus 2 sehingga kondisi pembelajaran lebih terkontrol dan berjalan kondusif. Peserta didik sudah mampu dalam menempatkan diri sebagai pusat pembelajaran sehingga kegiatan pembelajaran terlaksana sesuai konsep yaitu Student Center.

Hasil penelitian keterampilan berpikir kritis siklus 1 dan siklus 2 disajikan melalui tabel 2. 


\section{Tabel 2. Distribusi Frekuensi Keterampilan Berpikir Kritis Siklus I dan Siklus 2}

\begin{tabular}{|c|c|c|c|c|c|}
\hline \multirow{2}{*}{$\begin{array}{l}\text { Rentang } \\
\text { Skor }\end{array}$} & \multirow{2}{*}{$\begin{array}{c}\text { Klasifikasi } \\
\text { Keterampilan } \\
\text { Berpikir Kritis }\end{array}$} & \multicolumn{2}{|c|}{ Siklus 1} & \multicolumn{2}{|c|}{ Siklus 2} \\
\hline & & Frekuensi & Persentase & Frekuensi & Persentase \\
\hline 76-100 & $\begin{array}{l}\text { Keterampilan berpikir } \\
\text { kritis sangat baik }\end{array}$ & - & - & 9 & $45 \%$ \\
\hline $51-75$ & $\begin{array}{l}\text { Keterampilan berpikir } \\
\text { kritis baik }\end{array}$ & 3 & $15 \%$ & 8 & $40 \%$ \\
\hline $26-50$ & $\begin{array}{l}\text { Keterampilan berpikir } \\
\text { kritis cukup }\end{array}$ & 8 & $40 \%$ & 3 & $15 \%$ \\
\hline $0-25$ & $\begin{array}{l}\text { Keterampilan berpikir } \\
\text { kritis kurang }\end{array}$ & 9 & $45 \%$ & - & - \\
\hline Jumlah & & 20 & $100 \%$ & 20 & $100 \%$ \\
\hline
\end{tabular}

Sumber: Data primer

Berdasar pada tabel 2, nampak bahwa keterampilan peserta didik dalam berpikir kritis ketika siklus 1 adalah peserta didik dengan kriteria keterampilan berpikir kritis kurang terdapat 9 peserta didik atau 45\% dari jumlah keseluruh, peserta didik yang memiliki kategori cukup terdapat 8 atau 40\% dari seluruh peserta didik, dan terdapat. 3 peserta didik atau $15 \%$ dari seluruh peserta didik yang sudah tergolong baik dalam keterampilan berpikir kritis.

Kegiatan pembelajaran dengan PBL pada siklus 2 menggunakan Tema 6 "Energi dan Perubahannya" subtema 2 "Perubahan Energi". Tahapan siklus 1 sama dengan siklus 2, yakni dimulai dengan perencanaan, pelaksanaan serta observasi, dan refleksi. Hasil keterampilan berpikir kritis siklus 2 secara rinci disajikan melalui tabel 2.

Berdasar tabel 2 pelaksanaan siklus 2 nampak bahwa terjadi penurunan persentase keterampilan pada peserta didik untuk berpikir kritis kurang menjadi tidak ada. Jumlah peserta didik di kelas yang mampu untuk memiliki keterampilan berpikir kritis cukup terdapat 3 dari 20 peserta didik atau 15\% dari seluruh peserta didik. Jumlah peserta didik yang memiliki keterampilan berpikir kritis baik terdapat 8 dari 20 peserta didik atau 40\% dari seluruh pesertadidik dan peserta didik yang memiliki keterampilan berpikir kritis sangat baik terdapat 9 dari 20 peserta didik atau $45 \%$ dari seluruh peserta didik.

Akibat dari peningkatan klasifikasi keterampilan peserta didik untuk dapat berpikir kritis terjadi karena tindakan pembelajaran berupa desain pembelajaran menggunakan pendekatan PBL. Bukti peningkatan ditunjukkan oleh hasil penelitian ini yang memberikan tindakan pada pembelajaran Tema 6 Energi dan Perubahannya dengan desain pembelajaran PBL yang melibatkan peserta didik kelas III di SD N 10 Purwodadi dapat meningkatkan keterampilan berpikir kritis dengan baik. Peningkatan terjadi dikarenakan dalam pelaksanaan pembelajaran peserta didik didesain untuk mampu mereview masalah dengan mencatat 3 masalah tentang energi, menanya 3 masalah tentang energi, menalar pemecahan 3 masalah tentang energi, mengumpulkan data tentang energi, menganalisis data tentang energi, menulis laporan hasil penyelesaian 3 masalah tentang energi, menyajikan hasil bukti penyelesaian masalah tentang energi, dan melakukan evaluasi terhadap bukti proses pemecahan masalah tentang energi.

Ketika kegiatan belajar mengajar dengan PBL, peran pendidik sebagai fasilitator serta motivator. Peserta didik mampu terlibat dalam pembelajaran PBL, yang nampak melalui aktivitas peserta didik dalam upaya untuk menemukan berbagai jawaban yang digunakan guna 
menyelesaikan masalah tentang sumber energi, pembelajaran berjalan menyenangkan, nampak dari respon peserta didik dalam melaksanakan setiap tahapan pembelajaran yang diarahkan oleh guru. Peserta didik berani dan mampu mengajukan pertanyaan apabila dalam pelaksanaan penyelesaian masalah menemui hambatan dan peserta didik antusias dalam mengikuti proses pembelajaran, nampak dalam kegiatan menarik kesimpulan dari penyelesaian masalah dan evaluasi terhadap kesimpulan yang diperoleh dari kegiatan memecahkan masalah. Peserta didik mampu mengungkapkan hasil penyelesaian masalahnya dengan tepat dan peserta lainnya mampu merespon presentasi temannya dengan memberikan komentar atau saran terhadap hasil penyelesaian masalah peserta didik. Selama proses pembelajaran, guru mengarahkan peserta didik untuk memecahkan masalah. Permasalahan yang muncul dibuat relevan dengan permasalahan yang terjadi pada kehidupan sehari-hari, sehingga dapat menyiapkan peserta didik dalam menjalani kehidupannya. Kegiatan pembelajaran memunculkan solusi-solusi yang bersumber dari peserta didik dan disampaikan oleh peserta didik.

Ketika pelaksanaan pembelajaran, pendekatan PBL mampu untuk meningkatkan keterampilan peserta didik dalam berpikir kritis. Hal ini dibuktikan dengan meningkatnya keterampilan peserta didik dalam berpikir kritis pada setiap siklus pembelajaran. Maka, dengan hasil yang didapatkan dalam penelitian, maka dapat diungkapkan bahwa pembelajaran PBL mampu meningkatkan keterampilan peserta didik dalam berpikir kritis.

Hasil penelitian yang telah dilakukan diperkuat dengan pelaksanan penelitian yang telah dilakukan oleh (Pusparini, 2019) yang memperoleh hasil bahwa pelaksanan pembelajaran dengan Problem Based Learning mampu untuk meningkatkan keterampilan berpikir kritis bagi peserta didik yang disiklus I terdapat 62,5\% peserta didik namun setelah dilaksanakan siklus II menjadi sebesar 90,6\% dari keseluruhan peserta didik di kelas. Penelitian lain juga dilaksanakan oleh (Kurniasih, 2017) dengan hasil pada siklus 1 memperoleh hasil $75 \%$ peserta didik yang memiliki keterampilan berpikir kritis menjadi 87\% peserta didik yang mampu memiliki keterampilan berpikir kritis setelah dilaksanakannya pembelajaran siklus II. Penelitian yang sama juga dilakukan oleh (Oktaviana et al., 2016) dengan hasil peningkatan terjadi pada siklus II dimana peneliti memperoleh hasil kategori tinggi 68,75\%, sedang 25\% dan rendah 6,25\% dari jumlah keseluruhan peserta didik.

Berdasar pada hasil pelaksanaan penelitian yang telah dilakukan dan kajian penelitian yang telah dilaksanakan oleh peneliti yang lain. Maka, kesimpulan yang diperoleh bahwa pembelajaran dengan penerapan pendekatan PBL mampu untuk meningkatkan keterampilan peserta didik dalam berpikir kritis.

\section{SIMPULAN}

Berdasar hasil pelaksanaan penelitian dan serta pembahasannya. Jadi, dapat ditarik sebuah simpulan bahwa: 1) Dengan pelaksanana penelitan terdapat peningkatan keterampilan berpikir kritis peserta didik yang diupayakan dengan pembelajaran PBL, yang dibuktikan dengan 15\% dari seluruh peserta didik memiliki keterampilan berfikir kritis baik pada siklus 1 meningkat menjadi 40\% dari seluruh peserta didik memiliki keterampilan berpikir kritis baik pada siklus 2. Pada siklus 1 tidak terdapat peserta didik yang memiliki keterampilan berpikir kritis sangat baik, pada siklus 2 terdapat $45 \%$ dari jumlah keseluruhan dari peserta didik yang memiliki keterampilanberpikir kritis sangat baik. 2) Upaya peningkatan keterampilan berpikir kritis peserta didik dalam pembelajaran PBL diupayakan dengan langkah: mereview masalah dengan mencatat 3 masalah sumber energi, menanya 3 masalah sumber energi, menalar pemecahan 3 masalah sumber energi, mengumpulkan data sumber energi, menganalisis data sumber energi, menulis laporan hasil penyelesaian 3 masalah sumber energi, menyajikan hasil dari tindakan penyelesaian masalah sumber energi, dan melakukan evaluasi proses pemecahan masalah sumber energi.

Dengan adanya hasil penelitian ini diharapkan guru berkomitmen untuk melaksanakan pembelajaran PBL. Saran untuk kepala sekolah, diharapkan kepala sekolah bisa memberikan 
semangat mengajar kepada guru untuk membentuk pembelajaran yang inovasi ketikapelaksanaan pembelajaran di kelas.

\section{DAFTAR PUSTAKA}

Alghafri, A. S. R., \& Ismail, H. N. Bin. (2014). The Effects of Integrating Creative and Critical Thinking on Schools Students' Thinking. International Journal of Social Science and Humanity, 4(6), 518-525. https://doi.org/10.7763/ijssh.2014.v4.410

Eggen, P., \& Kauchak, D. (2012). Strategi dan Model Pembelajaran. PT. Indeks.

Eriyanti, E., \& Suryanti. (2018). Pengaruh Model Cps Terhadap Kemampuan Berpikir Kritis Pembelajaran Ipa Kelas Iv Sdn Kemuning Sidoarjo. Jurnal Pendidikan Guru Sekolaha Dasar, o6(9), 1548-1557.

Fakhrizal, T., \& Hasanah, U. (2020). DOI: 10.22373/biotik.v8i2.8222. 8(2), $200-217$. https://doi.org/10.22373/biotik.v8i2.8222

Hosnan. (2014). Pendekatan Saintifik dan Kontekstual dalam Pembelajaran Abad 21. Ghalia Indonesia.

Huda, M. (2013). Model-model Pengajaran dan Pembelajaran. Pustaka Pelajar.

Kurniasih, M. D. (2017). Pengaruh Pembelajaran React Terhadap Kemampuan Berpikir Kritis Matematis Ditinjau Dari Habit of Mind Mahasiswa. KALAMATIKA Jurnal Pendidikan Matematika, 2(1), 29. https://doi.org/10.22236/kalamatika.vol2no1.2017pp29-38

Kuswana, W. . (2013). Taksonomi Berpikir. PT. Remaja Rosdakarya.

Mawardi. (2018). Merancang model dan media pembelajaran. Scholaria: Jurnal Pendidikan Dan Kebudayaan, 8(1), 26-40. http://ejournal.uksw.edu/scholaria/article/view/1412

Mulyasa. (2014). Guru dalam Implementasi Kurikulum 2013. Remaja Rosdakarya.

Mustamilah. (2015). Peningkatan keterampilan proses dan hasil belajar menggunakan model. Scholaria, 5(No.2), 70-79.

Nismaya. (2020). Meningkatkan Kemampuan Berpikir Kritis melalui Model Pembelajaran Problem Based Learning. Simki.Unpkediri.Ac.Id, 6(2), 102-107. https://edarxiv.org/a4wzv/

Nurul 'azizah, A., \& Wardani, N. S. (2019). Upaya Peningkatan Hasil Belajar Matematika Melalui Model Project Based Learning Siswa Kelas V SD. Jurnal Riset Teknologi Dan Inovasi Pendidikan, 2(1), 194-204.

Oktaviana, I., Saputro, A., \& Utami, B. (2016). Upaya Peningkatkan Kemampuan Berpikir Kritis Dan Prestasi Belajar Siswa Melalui Penerapan Model Pembelajaran Problem Based Learning (Pbl) Dilengkapi Modul Pada Materi Kelarutan Dan Hasil Kali Kelarutan Kelas Xi Sma Negeri 1 Gondang. Jurnal Pendidikan Kimia Universitas Sebelas Maret, 5(1), 143-152.

Puisi, M., Kelas, S., Di, V., \& Negeri, S. M. P. (2013). Yang Diperoleh Lebih Besar Dari T. 1-11.

Pusparini, D. I. (2019). Pembelajaran Ilmu Pengetahuan Sosial Dengan Model. 1. https://journal.pgsdfipunj.com/index.php/ips/article/view/100

Rahmadani, N., \& Anugraheni, I. (2017). Peningkatan Aktivitas Belajar Matematika Melalui Pendekatan Problem Based Learning Bagi Siswa Kelas 4 Sd. Scholaria: Jurnal Pendidikan Dan Kebudayaan, 7(3), 241. https://doi.org/10.24246/j.scholaria.2017.v7.i3.p241-250

Rusman. (2012). Model-model Pembelajaran. PT. Rajagrafind Persada.

Suyatno. (2009). Menjelajah Pembelajaran Inovatif. Masmedia Buana Pustaka.

Wardani, N. S. (2014). Development of Student Character Through Project Based Learning For Social Studies Subjects. Widya Sari, 16 (2), 103-115.

Widana, I. W. (2018). Higher Order Thinking Skills Assessment towards Critical Thinking on Mathematics Lesson. International Journal of Social Sciences and Humanities (IJSSH), 2(1), 24-32. https://doi.org/10.29332/ijssh.v2n1.74

Yuyu Yuliati ; Dudu Suhandi Saputra. (2019). Jurnal cakrawala pendas. Jurnal Cakrawala Pendas, $5(2), 40-44$. 